\title{
Do $\beta$-chemokines Have Clinical Relevance in HIV Infection?
}

\author{
Carl E. Mackewicz, Edward Barker, Giampaolo Greco, Gustavo Reyes-Teran and Jay A. Levy
}

Department of Medicine and Cancer Research Institute, University of California, School of Medicine, San Francisco, California $94143-1270$

\begin{abstract}
The role of $\beta$-chemokines in HIV infection was evaluated. The kinetics of regulated upon activation of normal $\mathrm{T}$ cell expressed and secreted, macrophage inflammatory protein$1 \alpha$, and macrophage inflammatory protein $1 \beta$ production by stimulated $\mathrm{T}$ lymphocytes did not differ substantially between HIV-infected (asymptomatic and with AIDS) and uninfected subjects. Maximal production of these $\beta$-chemokines by activated peripheral blood cells was higher in the infected individuals than in uninfected individuals, but no significant difference was observed between healthy infected subjects and AIDS patients. Evaluation of the effect of HIV replication on $\beta$-chemokine production indicated that acute infection of CD4+ T cells with non-syncytia-inducing (NSI) viruses generally increased $\beta$-chemokine production two to eightfold, whereas with SI strains, it led to decreased production. The sensitivity of an individual's virus to $\beta$-chemokine-mediated inhibition correlated with the NSI virus phenotype and a healthy clinical state. $50 \%$ of the AIDS patients, however, had NSI viruses that were sensitive to $\beta$-chemokines. Finally, anti- $\beta$-chemokine-neutralizing antibodies caused a more rapid release of HIV by CD4+ T cells naturally infected by NSI, but not SI, viruses indicating that endogenously produced chemokines can affect HIV production in culture. These findings suggest that $\beta$-chemokines may affect HIV replication when an NSI virus is involved, but provide little evidence that they substantially influence HIV infection and pathogenesis. (J. Clin. Invest. 1997. 100: 921-930.) Key words: $\beta$-chemokines $\cdot$ CD4+ cells $\bullet$ CD8+ cells $\cdot$ HIV infection $\bullet$ neutralizing antibodies
\end{abstract}

\section{Introduction}

Chemokines (chemoattractant cytokines) are low molecular weight proteins that mediate inflammation via the recruitment of phagocytic and other immune cells (1). They have been found to be involved in several noninfectious inflammatory diseases (2-5), and have been implicated in the immune response to some infectious agents (6-8). Recent findings suggest that certain chemokines may play a role in HIV infection.

The present address of Gustavo Reyes-Teran is Department of Microbiology Research, National Institute of Respiratory Diseases, Mexico City, Mexico.

Address correspondence to Jay A. Levy, M.D., Box 1270, University of California, San Francisco, CA 94143-1270. Phone: 415-4764071; FAX: 415-476-8365.

Received for publication 26 February 1997 and accepted in revised form 14 May 1997.

J. Clin. Invest.

(C) The American Society for Clinical Investigation, Inc. 0021-9738/97/08/0921/10 \$2.00

Volume 100, Number 4, August 1997, 921-930

http://www.jci.org
First, regulated upon activation of normal T cell expressed and secreted (RANTES), ${ }^{1}$ macrophage inflammatory protein- $1 \alpha$ $(\mathrm{MIP}-1 \alpha)$, and macrophage inflammatory protein-1 $\beta$ (MIP$1 \beta)$, members of the $\beta$-chemokine family, were demonstrated to be potent inhibitors of HIV replication in vitro (9), although not all virus strains have been found to be sensitive to this antiviral activity (9-11). Second, the chemokine receptors CCR5 and CXCR4 (fusin) were shown to be efficient coreceptors for macrophage-tropic and $\mathrm{T}$ cell line-tropic strains of HIV, respectively (12-17). The viral determinant(s) regulating these cellular tropisms appears to be associated with the $\mathrm{V} 3$ region of the HIV envelope protein $(15,18-20)$. The ability of the $\beta$-chemokines to inhibit HIV replication likely reflects the competitive inhibition (after CD4 binding) of HIV attachment to the chemokine receptor(s) on target cells. Inhibitors of signaling pathways do not block the anti-HIV effects of the $\beta$-chemokines (19-21). Finally, CCR5 expression has been suggested to have clinical relevance (22-24). Some uninfected individuals with a history of repeated exposure to HIV are homozygous for a deletion mutation in CCR5, which prevents expression of this HIV coreceptor on the cell surface. CD4+ cells from these individuals are highly resistant to infection with a variety of macrophage-tropic isolates of HIV.

To evaluate further the potential clinical relevance of the $\beta$-chemokines in HIV infection, we performed cross-sectional analyses of RANTES, MIP- $1 \alpha$, and MIP- $1 \beta$ production by purified $\mathrm{T}$ cell subsets and $\mathrm{PBMC}$ from seronegative donors and $\mathrm{HIV}$-infected subjects at various stages of disease. The effect of HIV replication on $\beta$-chemokine production by $\mathrm{CD} 4+\mathrm{T}$ cells was also examined. Moreover, we sought to determine if there is a relationship between clinical state and sensitivity to $\beta$-chemokine-mediated virus inhibition. The findings suggest that $\beta$-chemokines have the potential to limit HIV replication in vivo, but that they do not prevent progression to disease.

\section{Methods}

Subjects. Heparinized peripheral blood samples were obtained by phlebotomy from HIV-1 seropositive and seronegative donors. The HIV-infected subjects were males between the ages of 25 and 50 . They were either clinically healthy and not receiving antiviral therapy, or they had an AIDS diagnosis based on the Centers for Disease Control criteria (25), but had no symptoms at the time of study. Most of the AIDS patients were taking antiretroviral drugs (e.g., 3' azido-3' deoxythymidine; $2^{\prime}, 3^{\prime}$ didoxoyinosine, or $2^{\prime}, 3^{\prime}$ dideoxy- $3^{\prime}$ thiacytidine) alone or in combination, but not a protease inhibitor. The asymptomatic subjects had a mean CD4+ cell count of 755 (range, 298-1,296) and a mean CD $4+$ cell percentage of 30 (range, 11-44\%). The AIDS patients had a mean CD4+ cell count of 226 (range, 18-518) and a mean CD4+ cell percentage of 14 (range, 4-26\%). Blood samples from

1. Abbreviations used in this paper: MIP-1 $\alpha$, macrophage inflammatory protein- $1 \alpha$; macrophage inflammatory protein-1 $\beta$; NSI, non-syncytium-inducing; RANTES, regulated upon activation normal $\mathrm{T}$ cell expressed and secreted; RT, reverse transcriptase; SI, syncytiuminducing; TCID $_{50}$, tissue culture infectious dose $\mathrm{S}_{50}$. 
HIV-seronegative donors were provided by Irwin Memorial Blood Centers (San Francisco, CA). The study received the approval of the Committee on Human Research, University of California, San Francisco.

Virus isolates. Primary HIV-1 isolates were obtained by cocultivating $3 \times 10^{6} \mathrm{PBMC}$ from the virus-infected subjects with $3 \times 10^{6}$ uninfected PBMC (from the seronegative donors) pretreated for $3 \mathrm{~d}$ with PHA $(3 \mu \mathrm{g} / \mathrm{ml})$ (Sigma Chemical Co., St. Louis, MO). The cocultured cells were grown in complete medium which consisted of RPMI 1640 medium (Cell Culture Facility, University of California, San Francisco) containing $10 \%$ heated $\left(56^{\circ} \mathrm{C}, 30 \mathrm{~min}\right) \mathrm{FCS}, 1 \%$ antibiotics (100 U/ml penicillin; $100 \mu \mathrm{g} / \mathrm{ml}$ streptomycin), $2 \mathrm{mM}$ glutamine, and $100 \mathrm{U} / \mathrm{ml}$ recombinant human IL-2 (Collaborative Biomedical Products, Bedford, MA). The cultures were passed every $3 \mathrm{~d}$, and the fluids were assayed for particle-associated reverse transcriptase (RT) activity (26). Culture fluids with RT levels of $\geq 50,000 \mathrm{cpm} / \mathrm{ml}$ were frozen at $-70^{\circ} \mathrm{C}$ for eventual preparation of virus stocks.

Stocks of primary viruses were prepared by inoculating the virus onto PHA-stimulated uninfected PBMC previously pretreated with polybrene $(10 \mu \mathrm{g} / \mathrm{ml}$ for $30 \mathrm{~min})$ (27). These cultures were grown in the RPMI 1640 complete medium and passed as described above. PHA-stimulated PBMC from the seronegative subjects were added on day 6 to increase virus yield. Virus stock fluids were harvested at or before peak viral release (as indicated by RT activity), usually 6-9 d after the addition of virus. Thus, the recovered viruses were only grown for short periods of time in culture and only in human PBMC.

The virus stocks were titered on PHA-stimulated PBMC obtained from the seronegative donors. Each virus stock was subsequently used at the dilution that yielded about $100,000 \mathrm{cpm} / \mathrm{ml}$ of RT activity on day 10 to ensure that approximately the same infectious virus input was used for each infection. The laboratory-passaged isolates used in this study were grown in PHA-stimulated uninfected PBMC, and were titered for tissue culture infectious dose ${ }_{50}\left(\mathrm{TCID}_{50}\right)$ as described (28).

The virus biologic phenotype was determined using an input dose of $\sim 100,000 \mathrm{cpm}$ of RT activity on the MT- 2 cell line as described (29). If syncytium formation and RT activity were present for at least two passages, the virus was considered to have a syncytia-inducing (SI) phenotype.

Recombinant $\beta$-chemokines and anti- $\beta$-chemokine neutralizing antibodies. Purified recombinant human RANTES, MIP- $1 \alpha$, and MIP-1 $\beta$ (Escherichia coli or SF-21 expressed) were obtained from R\&D Systems (Minneapolis, MN). An equal mixture of recombinant RANTES, MIP- $1 \alpha$, and MIP-1 $\beta$ was usually prepared to a concentration of $100 \mu \mathrm{g} / \mathrm{ml}$ each, and dilutions thereof were tested in culture for their effects on virus production.

Polyclonal goat antiserum specific for human RANTES, MIP- $1 \alpha$, or MIP-1 $\beta$, and the nonspecific control goat serum were obtained from R\&D Systems. The lyophilized preparation of each antichemokine antibody was reconstituted in PBS to $3 \mathrm{mg} / \mathrm{ml}$, and a stock mixture was prepared containing $1 \mathrm{mg} / \mathrm{ml}$ of anti-RANTES, $0.5 \mathrm{mg} / \mathrm{ml}$ of antiMIP $-1 \alpha$, and $1 \mathrm{mg} / \mathrm{ml}$ of anti-MIP- $1 \beta$ antibodies. The final antibody concentration used in experiments was $100 / 50 / 100 \mu \mathrm{g} / \mathrm{ml}$ of antibodies to RANTES, MIP-1 $\alpha$, and MIP-1 $\beta$, respectively. In the neutralization experiments, antibody was added at the initiation of the culture, and was replenished every $3 \mathrm{~d}$ upon medium exchange. The ability of these antibodies to neutralize a mixture of the recombinant human $\beta$-chemokines (each at $100 \mathrm{ng} / \mathrm{ml}$ ) was confirmed in functional assays as well as by ELISA.

Production of RANTES, MIP-1 $\alpha$, and MIP-1 $\beta$ by peripheral blood cells. $\beta$-chemokine production by PBMC and CD4+ T cells was examined after PHA stimulation. CD4+ cells were isolated from PBMC using anti-CD4 immunomagnetic beads as described (30), resulting in $\geq 95 \% \mathrm{CD} 4+/ \mathrm{CD} 3+$ cells $(<1 \% \mathrm{CD} 8+$ cells $)$ as assessed by flow cytometric analyses (31). PBMC and purified CD4+ cells were cultured in the RPMI 1640 complete medium in the presence of $3 \mu \mathrm{g} / \mathrm{ml}$ of PHA for $3 \mathrm{~d}$ at a cell density of $3 \times 10^{6} / \mathrm{ml}$. The cells were then washed and passed every 2 or $3 \mathrm{~d}$ adjusting to $2 \times 10^{6} \mathrm{cells} / \mathrm{ml}$ at each passage. The collected culture fluid was filtered $(0.45 \mu \mathrm{m})$ and stored frozen at $-70^{\circ} \mathrm{C}$ until tested. The heat-inactivated FCS and recombinant human IL-2 used in cell culture, did not contain any antigenically cross-reactive RANTES, MIP- $1 \alpha$ or MIP- $1 \beta$, as detectable by ELISA for the human $\beta$-chemokines.

Induction of $\beta$-chemokine production by $\mathrm{CD} 8+\mathrm{T}$ cells was achieved by antibody-mediated cross-linking of the CD3 molecule on the cell surface as described (10). CD $8+$ cells $(\geq 95 \% \mathrm{CD} 8+/ \mathrm{CD} 3+$, $<1 \% \mathrm{CD} 4+$ ) were mixed with anti-CD3-coupled immunomagnetic beads (27) at a bead-to-cell ratio of $\sim 3: 1$, and cultured for three days in the complete medium containing IL-2. After washing the cells, the culture fluids were collected every $2 \mathrm{~d}$, and the cells were passed with fresh medium. Essentially, the same culture conditions used for measuring chemokine production by $\mathrm{CD} 4+$ cells were used for the $\mathrm{CD} 8+$ T cells.

Spontaneous chemokine production was assessed in culture fluids collected $24-48 \mathrm{~h}$ after plating $3 \times 10^{6}$ nonstimulated cells $/ \mathrm{ml}$ in IL-2-supplemented complete culture medium.

For the experiments analyzing the effect of HIV replication on $\beta$-chemokine production by acutely infected CD4 $+\mathrm{T}$ cells, nonsyncytia-inducing (NSI) and syncytia-inducing (SI) primary isolates $\left(4 \mathrm{TCID}_{50} / 10^{6}\right.$ cells) were used to infect PHA-stimulated purified CD4 + T cells from seronegative donors. For several experiments, the molecular clone of an SI virus, $\mathrm{HIV}-1_{\mathrm{SF} 2}(32),\left(40 \mathrm{TCID}_{50} / 10^{6}\right.$ cells), was used. The infected cells were cultured and monitored as described above for the production of chemokines by mitogen-stimulated CD4 $+\mathrm{T}$ cells. In all experiments, the concentration of the human $\beta$-chemokines in cell culture fluids was measured by ELISA (Quantikine kits, R\&D Systems), usually in duplicate according to the manufacturer's instructions.

Chemokine-mediated inhibition of HIV replication in naturally and acutely infected CD4+ T cells. The effect of a mixture of recombinant human RANTES, MIP- $1 \alpha$, or MIP- $1 \beta$ on HIV replication in naturally infected CD4+ cells was assessed by procedures previously described $(10,27)$. In brief, naturally infected CD4+ cells after isolation were cultured in duplicate for $3 \mathrm{~d}$ with PHA $(3 \mu \mathrm{g} / \mathrm{ml})$ in complete medium supplemented with $200 \mathrm{U} / \mathrm{ml}$ of human recombinant IL-2. Cell cultures were subsequently passed every $3 \mathrm{~d}$. The culture supernatants from each time point were monitored for RT activity. The recombinant chemokine mixture was added at the initiation of culture, and every third day thereafter upon cell passage.

Acutely infected CD4+ T cells were prepared as described (30). In brief, PHA-stimulated CD4+ T cells from HIV seronegative control subjects were inoculated with comparable levels of primary viruses (see Methods) and 500-1,000 $\mathrm{TCID}_{50}$ of laboratory-passaged HIV isolates. After a 1-h incubation, the cells were washed and plated (in triplicate) in 96-well culture plates $\left(10^{5}\right.$ cells/well). The infected CD4+ cells were cultured alone or in the presence of various concentrations of $\beta$-chemokines, as described above for naturally infected CD $4+$ cells. These cultures were passed every $2 \mathrm{~d}$, replenished with fresh chemokine(s), and the culture fluid monitored for RT activity. CD4+ cells from only four donors were used to minimize possible variation in virus replication in $\mathrm{CD} 4+$ cells from different donors (33).

Statistical analysis. Differences in the mean levels of the $\beta$-chemokines produced by PBMC and by $\mathrm{CD} 4+$ and $\mathrm{CD} 8+\mathrm{T}$ cells from the different clinical groups was statistically evaluated using the MannWhitney U test. Spearman rank correlation tests were used to analyze the relationship of chemokine production to peripheral blood CD4+ cell counts and percentages.

\section{Results}

Kinetics and levels of $\beta$-chemokine production by $C D 4+$ and $C D 8+T$ cells from uninfected and HIV-infected subjects. RANTES, MIP-1 $\alpha$, and MIP-1 $\beta$ were produced by mitogenstimulated CD4 + T cells (Fig. 1) and CD8 + T cells (Fig. 2) 
A

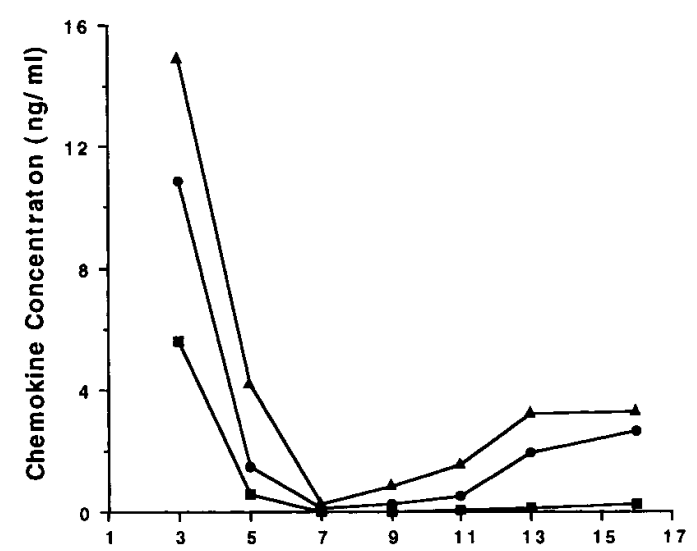

B

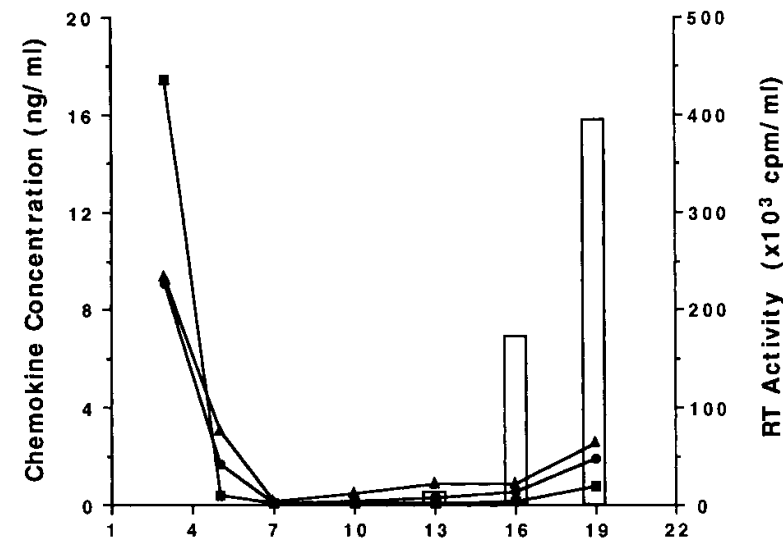

C

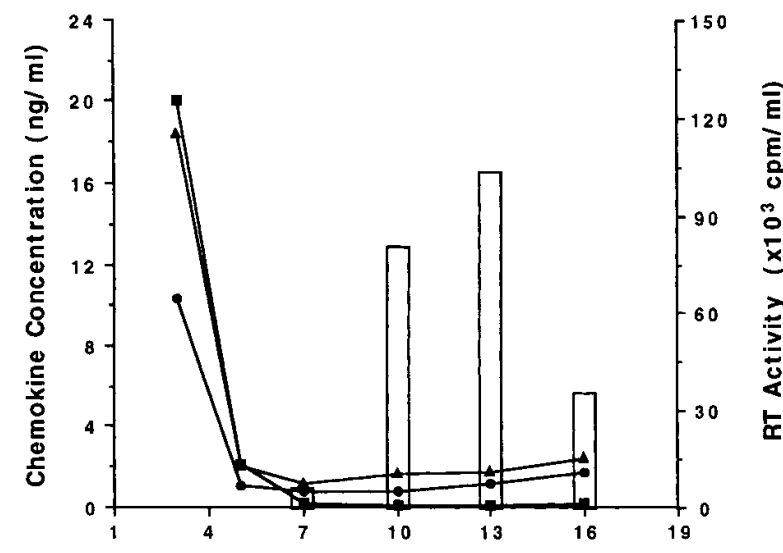

D

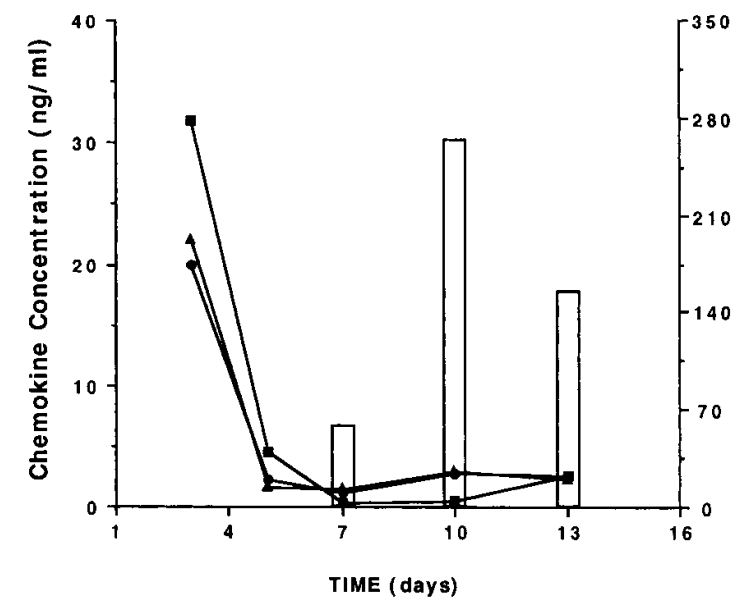

with similar kinetic profiles. Cells from uninfected and HIVinfected subjects, whether asymptomatic or with an AIDS diagnosis, showed kinetics of $\beta$-chemokine production that were similar. All three chemokines were produced by both $\mathrm{T}$ cell subsets at highest levels early after activation (within $72 \mathrm{~h}$ ). By days 5-7 after stimulation, the levels of chemokines produced decreased sharply, and then usually rose slightly over the next $9 \mathrm{~d}$. RANTES production was often the lowest of the three chemokines. Endogenous HIV production by CD4+ cells did not appear to affect this pattern of chemokine production (Fig. 1, B-D) (see below).

$\beta$-chemokine production by $T$ cells and PBMC from $H I V$-infected subjects is increased but does not correlate with clinical status. Having determined the kinetics of maximal $\beta$-chemokine production by CD4+ and CD8 $+\mathrm{T}$ cells, we expanded the number of subjects examined to assess the relationship between the extent of peak $\beta$-chemokine production by peripheral blood cells and the clinical state. With stimulated CD4+ T cells from uninfected donors, the peak levels of RANTES, MIP- $1 \alpha$, and MIP-1 $\beta$ produced were comparable, ranging from undetectable to $12.6,0.6-44$, and $1.0-21.6 \mathrm{ng} / \mathrm{ml}$, respectively (Fig. 3). The mean level of MIP- $1 \alpha(16.3 \pm 13.5 \mathrm{ng} /$ $\mathrm{ml})$ was highest $(P<0.01$ compared to MIP-1 $\beta)$, followed by MIP-1 $\beta(7.3 \pm 5.2 \mathrm{ng} / \mathrm{ml})(P<0.001$ compared to RANTES $)$, and then RANTES $(3.5 \pm 3.6 \mathrm{ng} / \mathrm{ml})$.

With CD4+ T cells from HIV-infected individuals, whether asymptomatic or diagnosed with AIDS, the maximal $\beta$-chemokine production was considerably more variable. Some individuals produced extremely high levels of these chemokines (> $100 \mathrm{ng} / \mathrm{ml}$ ) (Fig. 3). In general, a strong correlation was seen between the level of one chemokine and the levels of the other two. Compared to the seronegative group, CD4+ T cells from HIV-infected asymptomatic individuals produced 3-10fold higher mean maximal levels of the $\beta$-chemokines $(P<$ 0.001 in each case). CD4+ T cells from the AIDS patients produced 4-20-fold higher levels of these chemokines than did CD4+ T cells from the seronegative donors $(P<0.001$ in each case). Although the mean levels of RANTES and MIP-1 $\beta$ produced were higher by CD4+ T cells from AIDS patients than asymptomatic HIV-infected subjects (67.3 vs. 35.3 , and 73.7 vs. $22.8 \mathrm{ng} / \mathrm{ml}$, respectively), the differences in the mean levels produced by the cells from these two clinical groups were not significant. Furthermore, no correlation was found between maximal chemokine production and either an individual's peripheral blood CD4+ cell count or percentage (data not shown).

Figure 1. Kinetics of $\beta$-chemokine production relative to HIV production by activated CD4+ T cells. The levels of RANTES ( $\mathbf{\square})$, MIP-1 $\alpha(\mathbf{\Lambda})$, and MIP-1 $\beta(\bullet)$ produced over time in culture by $\mathrm{CD} 4+\mathrm{T}$ cells from an HIV seronegative subject $(A)$, an asymptomatic HIV seropositive subject $(B)$, and AIDS patients with an NSI $(C)$ or an SI $(D)$ virus are shown. Purified CD4+ T cells were stimulated for $3 \mathrm{~d}$ with $3 \mu \mathrm{g} / \mathrm{ml}$ of PHA and subsequently passaged every $2-3 \mathrm{~d}$ by exchanging the entire amount of culture fluid with fresh culture medium. The concentration of chemokines in the cell culture fluids was measured by ELISA (Quantikine kits; R\&D Systems) in duplicate. The results represent the average amount of chemokine produced by $3 \times 10^{6}$ cells $/ \mathrm{ml}$. HIV production (indicated by vertical bars) in the culture fluids was quantified by measuring reverse transcriptase (RT) activity (26). The results are representative of experiments with 5-9 different subjects from each group. 
A

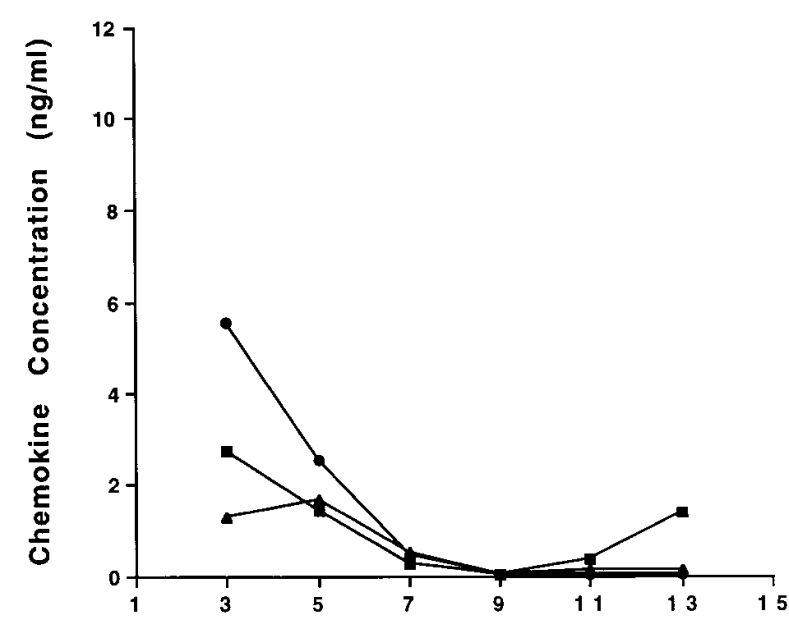

B

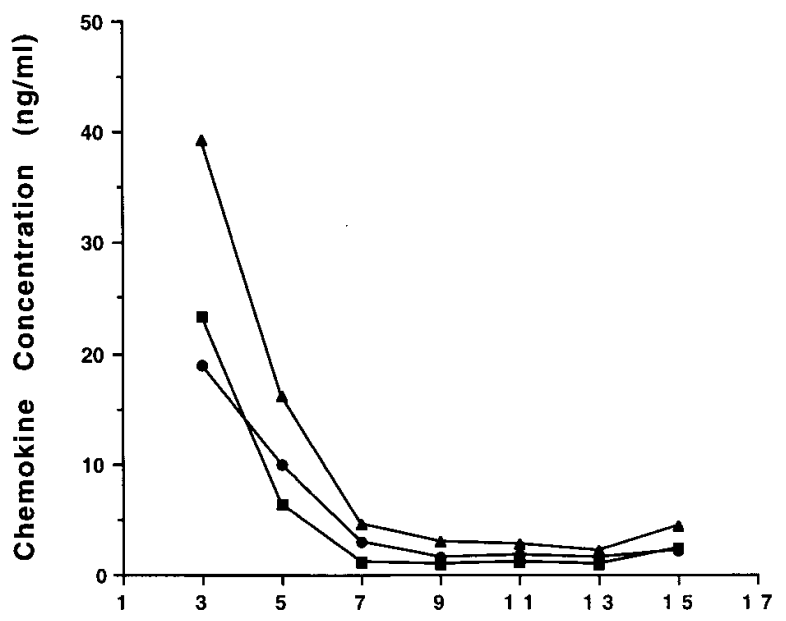

C

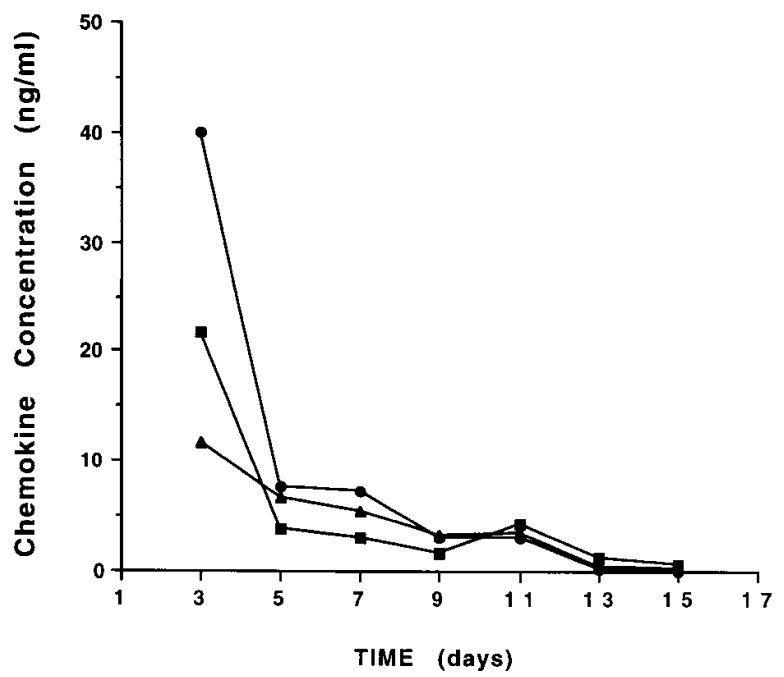

Figure 2. Kinetics of $\beta$-chemokine production by activated CD8+ T cells. The levels of RANTES (ם), MIP-1 $\alpha(\boldsymbol{\Delta})$, and MIP-1 $1 \beta(\bullet)$ produced over time in culture by CD8+ T cells from an HIV-seronegative subject $(A)$, an asymptomatic HIV seropositive subject $(B)$, and an AIDS patient $(C)$ are shown. Purified CD8+ T cells were stimulated for $3 \mathrm{~d}$ with $\alpha$-CD3-coated immunomagnetic beads (10) and subsequently passaged every $2-3 \mathrm{~d}$ by exchanging the entire amount
When stimulated CD8 $+\mathrm{T}$ cells were studied, maximal $\beta$-chemokine production in general mirrored that seen with CD4+ T cells (Fig. 3). In relation to seronegative subjects, $\mathrm{CD} 8+$ cells from HIV-infected individuals produced four to sevenfold higher levels of RANTES and MIP- $1 \alpha$, but in contrast to findings with CD4+ T cells, did not produce significantly higher mean levels of MIP-1 $\beta$. CD8 $+\mathrm{T}$ cells from the AIDS patients produced less RANTES and MIP- $1 \alpha$ on average than did cells from asymptomatic HIV-infected subjects, but this difference was not statistically significant. Furthermore, as noted with CD4+ T cells, no correlation was observed between chemokine production by CD8+ T cells and either peripheral blood CD4+ cell count or CD4+ cell percentage (data not shown).

$\beta$-chemokine production from stimulated PBMC was analyzed to take into consideration the combined chemokine production by natural killer cells (34), B cells (35), and macrophages $(36,37)$, as well as $\mathrm{T}$ cells at their natural proportion in the peripheral blood. The results obtained were similar to those observed with CD8+ cells (Fig. 3). Significantly higher levels of RANTES and MIP-1 $\alpha$ were produced by HIV-infected subjects when compared to seronegative individuals $(P<0.001)$. No significant difference in chemokine production, however, was noted between cells from asymptomatic HIV-infected subjects and those from AIDS patients. Again, no correlation of chemokine production to peripheral blood CD4+ cell counts and percentages was observed (data not shown).

When spontaneous production of $\beta$-chemokines was measured, the unstimulated CD4+ and CD $8+$ T cells from HIV seronegative individuals made very low amounts, usually $<500$ $\mathrm{pg} / \mathrm{ml}$ (data not shown). In contrast, the unstimulated CD4+ cells from the HIV-infected subjects (both asymptomatic and with AIDS) tended to produce higher levels of all three $\beta$-chemokines (up to $1,400 \mathrm{pg} / \mathrm{ml}$ ). Unstimulated CD8+ cells from HIV-infected subjects produced low levels of chemokines comparable to those produced by CD8+ cells from uninfected controls $(<500 \mathrm{pg} / \mathrm{ml})$.

Effect of HIV replication in CD4+ T cells on the production of RANTES, $M I P-1 \alpha$, and MIP-1 $\beta$. Since HIV replication has been shown to alter the expression of certain cytokines (38), we studied the effects of virus infection on $\beta$-chemokine production by CD4+ T cells. As described above (Fig. 1, B-D), naturally infected CD4+ cells, releasing virus over the period from days 7-19 after mitogen stimulation, showed a pattern of chemokine production similar to that seen in stimulated uninfected CD4+ T cells (Fig. 1) or CD4+ T cells from infected individuals that did not release detectable virus (data not shown). In contrast to these findings with endogenous virus production, acute HIV infection led to an increase or decrease in $\beta$-chemokine production depending on the viral phenotype used. Cultured CD4+ T cells from seronegative donors were acutely infected with a low input of NSI and SI HIV-1 isolates. Most of the viruses used showed peak replication in CD4+ cells on day 10-13 after inoculation (usually reaching

of culture fluid with fresh culture medium. The concentration of chemokines in the cell culture fluids was measured by ELISA (Quantikine kits; R\&D Systems) in duplicate. The results represent the average amount of chemokine produced by $3 \times 10^{6}$ cells $/ \mathrm{ml}$. The data are representative of experiments with 8-10 different subjects from each group. 

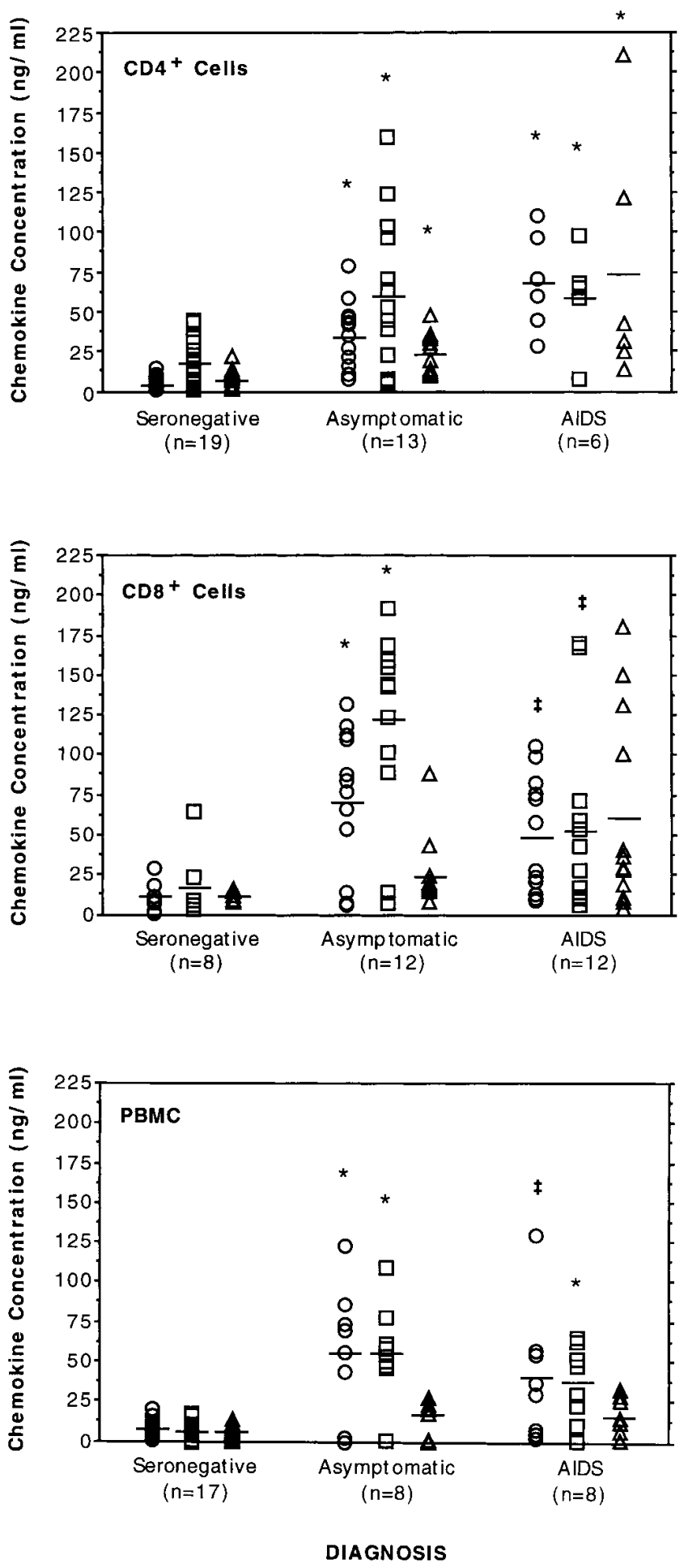

Figure 3. Maximal $\beta$-chemokine production by activated peripheral blood cells. The levels of RANTES $(\bigcirc)$, MIP- $1 \alpha(\square)$, and MIP-1 $\beta$ $(\triangle)$ produced by CD4+ T cells, CD8 + T cells, and PBMC from HIV-seronegative subjects, asymptomatic HIV seropositive subjects, and AIDS patients are shown. CD4+ T cells and PBMC were stimulated with PHA for $3 \mathrm{~d}$, whereas the CD8+ T cells were stimulated for the same period with $\alpha$-CD3 antibody-coated immunomagnetic beads (10). The concentration of $\beta$-chemokines in the cell culture fluid collected on day 3 was measured by ELISA (Quantikine kits; $\mathrm{R} \& \mathrm{D}$ Systems) in duplicate. The results represent the average amount of chemokine produced by $3 \times 10^{6} \mathrm{cells} / \mathrm{ml}$. A statistically sig- an RT activity of $>5 \times 10^{4} \mathrm{cpm} / \mathrm{ml}$ ). In these studies, the number of cells in the infected cultures was always less than that in the uninfected cell cultures. This result most likely reflects the cytopathic effects of HIV-1. To compensate for this difference, the levels of $\beta$-chemokine measured were analyzed per cell number.

After acute infection by six different NSI primary virus isolates, an increased production (2.5-8-fold) of the three chemokines (particularly RANTES) was generally observed (Fig. 4). The increases observed usually followed peak HIV production. We chose one NSI strain, HIV-1 $1_{\mathrm{SV}}$, to examine further the consistency of the results, and in more than 10 experiments found this enhancing effect to be very reproducible. The levels of RANTES and MIP- $1 \alpha$ were usually increased, while MIP-1 $\beta$ levels were either increased or not affected. In contrast, in CD4+ $\mathrm{T}$ cells infected with three different SI viruses (two primary and one laboratory-passaged), a reduction of $\beta$-chemokine production was usually noted (Fig. 4). Again, detailed examination of one of these SI viruses (HIV-1 $1_{\mathrm{SF} 2}$ ), in six different experiments consistently showed this reduction in chemokine production. Thus, the effect of acute infection on $\beta$-chemokine production by CD4 $+\mathrm{T}$ cells appears to be dependent on the biologic phenotype of the virus strain used.

$H I V$ sensitivity to inhibition by the $\beta$-chemokines correlates strictly with the HIV phenotype and marginally with the clinical state. Previous studies indicated that HIV-1 isolates can vary in the extent to which their replication in acutely infected CD $4+$ cells is inhibited by the $\beta$-chemokines $(9,10)$. To determine if there is any clinical relevance to these observations, we evaluated the biologic phenotype and measured the extent of $\beta$-chemokine sensitivity of 22 primary and 7 laboratory-passaged HIV isolates. Both primary and laboratory HIV isolates could be categorized as $\beta$-chemokine-sensitive or -insensitive, based on whether their replication in acutely infected CD4+ cells was sensitive to inhibition ( $\geq 50 \%$ reduction of RT activity) by an equal mixture of recombinant RANTES, MIP- $1 \alpha$, and MIP-1 $\beta$ (Table I). In the cases tested, if a virus was not inhibited by $500 \mathrm{ng} / \mathrm{ml}$ of the $\beta$-chemokine mixture, it was also not affected by concentrations as high as $20 \mu \mathrm{g} / \mathrm{ml}$ (data not shown). Within the $\beta$-chemokine-sensitive group, the extent to which replication of different HIV isolates was inhibited varied from $88 \%$ suppression at $5 \mathrm{ng} / \mathrm{ml}$ to $51 \%$ at $500 \mathrm{ng} / \mathrm{ml}$. This range in sensitivities confirms previous observations (10).

Based on the above criteria, acute infection by 9 of 10 primary HIV isolates from asymptomatic individuals was sensitive to the inhibitory effects of $\beta$-chemokines, whereas the infection by only 6 of 12 HIV isolates from AIDS patients was sensitive (Table I). The sensitivity strictly correlated with the biologic phenotype of the virus; all NSI isolates were sensitive to the $\beta$-chemokines, whereas the SI viruses were resistant. Of the 15 NSI strains studied, only 7 were sensitive to the lowest concentration of $\beta$-chemokines tested $(5 \mathrm{ng} / \mathrm{ml}$ ) (data not shown). The difference in chemokine sensitivity of viruses recovered from the two clinical groups was of marginal significance $(P=0.05)$. Acute infection by five laboratory-grown HIV-1 and two HIV-2 isolates also showed an absolute corre-

nificant difference between the mean (vertical bar) of the denoted group and that of the corresponding seronegative group is indicated: $* P<0.001$ or ${ }^{\ddagger} P<0.01$. 
A

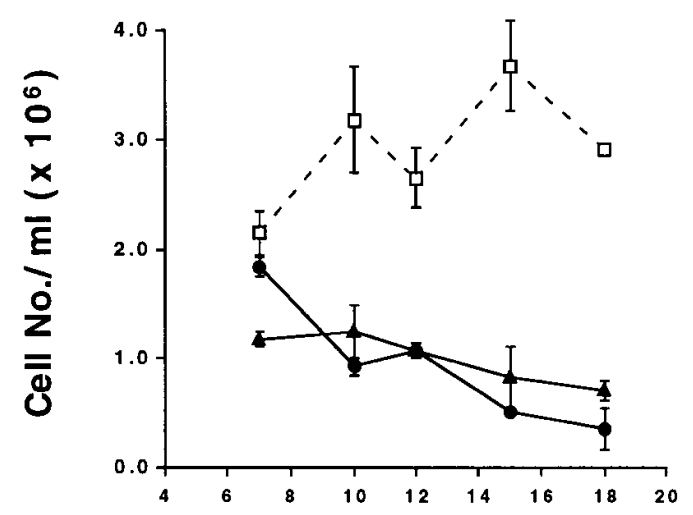

B
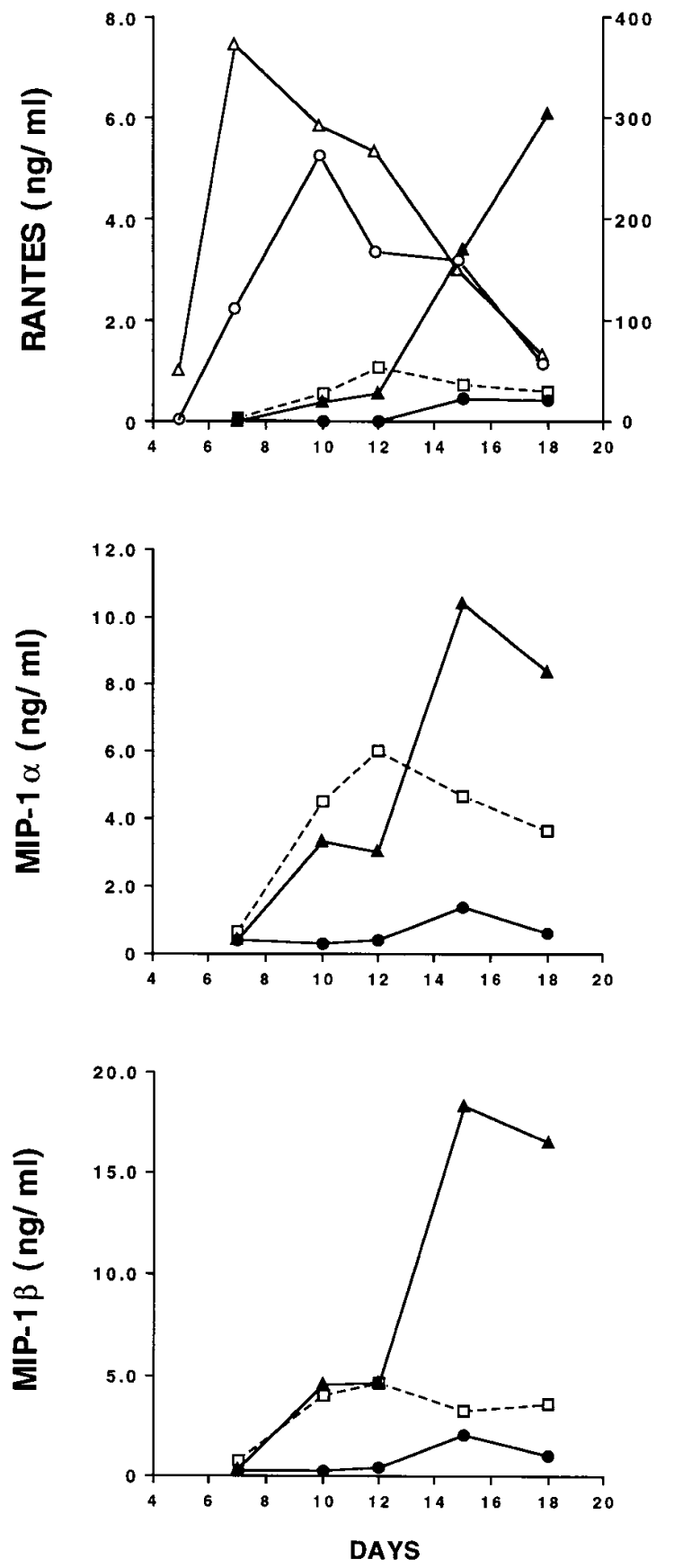

lation between chemokine sensitivity and the NSI phenotype. The HIV-1 NSI viruses, SF162 and SF128A, were sensitive, whereas the SI isolates, SF2, SF13, and SF33 were not. The NSI isolate of HIV-2, UCI, was sensitive; the SI isolate, UC2, was not.

To account for the possible influence of differences in viral load and CCR5 expression among subjects, we assessed the $\beta$-chemokine sensitivity of HIV replication in cultured naturally infected CD4+ cells of seven asymptomatic individuals and five AIDS patients. In agreement with the above findings, endogenous HIV replication in the CD4+ cells of five asymptomatic subjects (whose primary isolates were of the NSI phenotype) was sensitive to inhibition by the mixture of recombinant $\beta$-chemokines. The endogenous virus production by the CD4+ cells from the one asymptomatic subject with the SI primary virus isolate was insensitive (Table I). In the five AIDS patients examined, the CD4+ cells from three subjects having an NSI virus exhibited sensitivity to $\beta$-chemokine-mediated inhibition of virus replication. Virus in the CD4+ cells from the two subjects carrying an SI virus showed no sensitivity to $\beta$-chemokines (Table I). Experiments using individual recombinant $\beta$-chemokines also indicated that variations in sensitivity can be observed with CD4+ cells naturally infected with NSI viruses. In all cases, RANTES was the most potent inhibitor of HIV replication, followed by MIP-1 $\beta$ and MIP- $1 \alpha$ (data not shown). These in vitro results with naturally infected cells are in full agreement with those from acutely infected cells, and together demonstrate a strict relationship between chemokine sensitivity and virus phenotype.

Neutralization of endogenously produced $\beta$-chemokines enhances the onset of HIV production from naturally infected CD4+ T cells. To evaluate the effect of endogenously produced $\beta$-chemokines on HIV replication, a mixture of neutralizing antibodies to RANTES, MIP- $1 \alpha$ and MIP- $1 \beta$ was added to PHA-stimulated naturally infected $\mathrm{CD} 4+\mathrm{T}$ cells. These $\mathrm{CD} 4+\mathrm{T}$ cells, cultured in the continued presence of the neutralizing antibodies, showed a more rapid rise in endogenous virus replication than did $\mathrm{CD} 4+\mathrm{T}$ cells treated with control antibody (Fig. 5). High levels of HIV production were seen $3 \mathrm{~d}$ earlier when endogenously produced $\beta$-chemokines were neutralized $(<50 \mathrm{pg} / \mathrm{ml}$ of each, detectable by ELISA). By day $12-15$, this difference in the level of HIV produced was minimal. The control antibody-treated cell cultures had roughly $0.5-1.5 \mathrm{ng} / \mathrm{ml}$ and $1.5-3.3 \mathrm{ng} / \mathrm{ml}$ of the three chemokines on day 9 and day 12, respectively (Fig. 5). Increased replication of HIV in CD4 $+\mathrm{T}$ cells was also noted with antibodies to individual chemokines, but the use of the combination of antibodies to all three chemokines resulted in the highest levels of

Figure 4. Effect of acute HIV-1 infection on $\beta$-chemokine production. CD4+ cells from the same donor were infected with a low input $\left(\sim 4 \mathrm{TCID}_{50} / 10^{6}\right.$ cells) of an NSI $\left(\mathrm{HIV}-1_{\mathrm{NB}}\right)$ (triangles) or an SI $\left(\mathrm{HIV}-1_{\mathrm{EM}}\right)$ (circles) primary virus, or left uninfected as a control (-- $\left.\square--\right)$. After infection, the cell cultures were passed every 2-3 d. Each time the viable cell number $(A)$ was determined by trypan blue exclusion and the culture fluid was completely replaced with fresh medium. $(B)$ Virus replication (open triangles and circles) is indicated by the amount of RT activity in the culture fluid. $\beta$-chemokine production (closed symbols and open square) in the culture supernatants was measured by ELISA. These studies are representative of over 10 separate experiments using NSI and SI viruses (see text). 


\begin{tabular}{|c|c|c|c|c|c|c|}
\hline \multirow[b]{2}{*}{ Clinical state } & \multirow{2}{*}{$\begin{array}{c}\text { HIV } \\
\text { phenotype }\end{array}$} & \multicolumn{2}{|c|}{ Acute infection* } & \multicolumn{2}{|c|}{ Endogenous replication ${ }^{\ddagger}$} & \multirow[b]{2}{*}{ Total $^{\S}$} \\
\hline & & Sensitivell & Insensitive & Sensitive & Insensitive & \\
\hline \multirow[t]{2}{*}{ Asympt. } & NSI & 9 & 0 & $6^{\pi}$ & 0 & $14 / 14$ \\
\hline & SI & 0 & 1 & 0 & $1^{\pi}$ & $0 / 1$ \\
\hline \multirow[t]{2}{*}{ AIDS } & NSI & 6 & 0 & 3 & 0 & $9 / 9$ \\
\hline & SI & 0 & 6 & 0 & 2 & $0 / 8$ \\
\hline
\end{tabular}

*PHA-stimulated purified $\mathrm{CD}^{+}{ }^{+} \mathrm{T}$ cells from HIV-seronegative donors were acutely infected with similar inputs of primary isolates of HIV-1 obtained from asymptomatic subjects or AIDS patients (see text). ${ }^{\ddagger}$ Naturally infected CD $4{ }^{+} \mathrm{T}$ cells were cultured in duplicate. ${ }^{\S} \mathrm{The}$ total indicates the frequency of $\beta$ chemokine-sensitive viruses, excluding two cases in which the naturally infected cells were examined from an individual whose primary virus isolate was tested in the acute infection assay. Infected $\mathrm{CD} 4^{+} \mathrm{T}$ cells were cultured in triplicate in the continued presence of an equal mixture of the recombinant human chemokines RANTES, MIP- $1 \alpha$ and MIP- $\beta$ (see text). Control cultures contained no chemokines. A virus isolate was considered chemokine-sensitive if its replication (indicated by reverse transcriptase activity) was reduced $\geq 50 \%$ by exposure to the recombinant $\beta$-chemokines at $500 \mathrm{ng} / \mathrm{ml}$ or less in comparison to the control culture. ${ }^{\pi}$ One of these viruses was also tested by acute infection.

endogenous virus production (data not shown). Upon examination of several HIV-infected subjects, only those who carried a $\beta$-chemokine-sensitive virus showed this increase in the kinetics of virus release, regardless of whether they were asymptomatic or had AIDS (Fig. 6). The above results likely indicate that the neutralization of naturally produced $\beta$-chemokines from CD4+ T cells can affect the spread of HIV in culture.

\section{Discussion}

This study addressed four major questions relating to the potential clinical relevance of $\beta$-chemokines to HIV infection: $(a)$ Is $\beta$-chemokine production from peripheral blood cells of $\mathrm{HIV}$-infected individuals altered in comparison to cells from uninfected individuals and does the level of their production correlate to the clinical state?; $(b)$ does HIV replication affect $\beta$-chemokine production by CD4+ T cells?; $(c)$ does the sensitivity of the replication of an individual's virus to $\beta$-chemokine-mediated inhibition correlate to clinical state?; and $(d)$ do endogenously produced $\beta$-chemokines from CD4+ T cells affect the extent to which the cells replicate HIV?

With respect to the first question, our findings indicate that after activation, the production of RANTES, MIP- $1 \alpha$, and MIP-1 $\beta$ is substantially increased in peripheral blood cells from HIV-infected individuals as compared to uninfected controls. This increase is similar in both asymptomatic individuals and AIDS patients. As seen with many cytokines (39), maximal production of RANTES, MIP- $1 \alpha$, and MIP- $1 \beta$ from CD4+ cells, CD8+ T cells and PBMC occurred early after activation with mitogen (Figs. 1 and 2). The production of all three chemokines appeared to be tightly coregulated in both stimulated CD4+ and CD8+ T cells. The three chemokines were produced in amounts that were comparable to each other, and in general, cells producing the highest levels of one chemokine produced the highest levels of the other two (Fig. 3). The observed variability in chemokine production among individuals may reflect differences in the ability of their $\mathrm{T}$ cells to proliferate in response to mitogen (40-43), although we did not observe this to be true in all cases. Moreover, spontaneous chemokine production by the peripheral blood cells was also found to be quite variable. Similar findings on varying levels of chemokine production by $\mathrm{T}$ cells from HIV-infected or unin- fected individuals have been reported by others $(36,44)$

After stimulation, PBMC and both CD4+ and CD $8+\mathrm{T}$ cells from HIV-infected subjects exhibited a 3- to 20-fold increase in the mean levels of RANTES, MIP- $1 \alpha$, and MIP-1 $\beta$ produced relative to cells from uninfected individuals (Fig. 3). These levels (10-200 ng/ml) are well within the range required to block the production of some HIV isolates in vitro $(9,10)$. The elevated levels of chemokine production by these cells may relate to the activated state of immune cells in HIV infection (45). Because similar levels of chemokine production were observed with cells from asymptomatic subjects and AIDS patients (Fig. 3), and the level of production was not dependent on an individual's absolute count or percentage of peripheral blood CD4+ cells, we conclude that there is no correlation between clinical state and chemokine production by PBMC, CD4+, or CD8+ T cells. Other investigators in more limited studies have reached a similar conclusion in studies of CD8 + cells $(44,46)$ as well as all three of these cell populations (47). The elevated $\beta$-chemokine production in AIDS patients would suggest that these chemokines are not protecting against disease progression either by their ability to competitively inhibit HIV interaction with its coreceptor on CD4+ cells, or by a protective mechanism based on their chemotactic activities. The latter activities presumably regulate immune cell trafficking and inflammation (for review see reference 1).

In regard to the second question dealing with the effect of HIV infection on $\beta$-chemokine production, endogenous virus replication in CD4+ cells did not substantially alter the pattern of $\beta$-chemokine production by CD4+ cells (Fig. 1, $B-D$ ). In contrast, acute virus infection of purified CD4+ T cells quantitatively affected $\beta$-chemokine production depending on the virus strain used. Inoculation of CD4+ cells with primary $\beta$-chemokine-sensitive viruses (NSI phenotype) frequently showed increased $\beta$-chemokine production relative to the uninfected cells (Fig. 4). Acute infection by the SI viruses usually resulted in decreased production of all three chemokines. These findings do not support a clinical relevance of the $\beta$-chemokines since the increased production of these cytokines by NSI strains would have been expected to depress virus replication in culture, which did not occur (Fig. 4).

In connection with the third question about relative sensitivity of HIV isolates recovered at different clinical states, the viral sensitivity to $\beta$-chemokine inhibition was found to corre- 


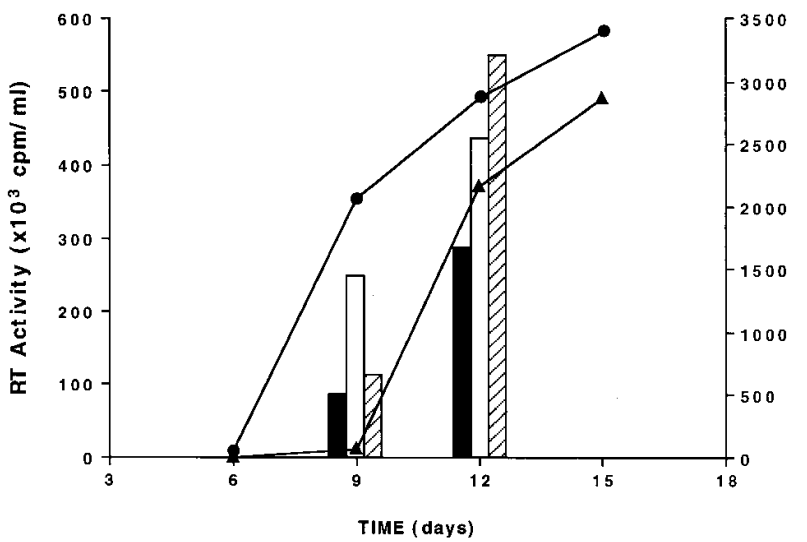

Figure 5. The effect of anti- $\beta$-chemokine neutralizing antibodies on the kinetics of HIV replication in naturally infected CD4+ T cells. The extent of HIV replication is indicated by RT activity in the culture fluids of CD4+ T cells isolated from an asymptomatic HIVinfected individual cultured (in duplicate) in the continued presence of either a nonspecific control antibody $(250 \mu \mathrm{g} / \mathrm{ml})(\mathbf{\Lambda})$ or a mixture of neutralizing antibodies specific to RANTES $(100 \mu \mathrm{g} / \mathrm{ml})$, MIP- $1 \alpha$ $(50 \mu \mathrm{g} / \mathrm{ml})$ and MIP-1 $\beta(100 \mu \mathrm{g} / \mathrm{ml})(\bullet)$. The concentration of

RANTES (solid bar), MIP-l $\alpha$ (open bar), and MIP-1 $\beta$ (striped bar) were measured in the culture fluids of the control antibody-treated cells on days 9 and 12 (see Methods). The results are representative of three separate experiments.

late to some extent. HIV isolates from AIDS patients are often insensitive because they have more SI viruses than do asymptomatic individuals. Acute infection by all NSI isolates was sensitive to the inhibitory activity of the $\beta$-chemokines (Table I) but at different levels ranging from substantial $(5 \mathrm{ng} / \mathrm{ml})$ to moderate $(50-500 \mathrm{ng} / \mathrm{ml})$. This correlation to biologic phenotype held true regardless of whether the virus was a primary or laboratory-passaged HIV-1 or HIV-2 isolate, and whether the primary isolate was from an asymptomatic individual or from an AIDS patient. This observation was also supported by the results showing $\beta$-chemokine-mediated inhibition of endogenous HIV replication in naturally infected CD4+ cells (Table I and Fig. 5). This latter finding may be more relevant to the natural setting because it reflects production of endogenous virus at the natural viral load in autologous cells (and autologous levels of chemokine receptor expression). The above results confirm and extend those of others evaluating the inhibition by chemokines of NSI and SI viruses (9-11).

In response to the clinical relevance of these findings, half (6/12) of the AIDS patients and one of the asymptomatic subjects studied harbored an SI virus in their blood that is insensitive to $\beta$-chemokines. Others have reported a similar prevalence of this phenotype in HIV-infected individuals and AIDS patients (48). Importantly, 50\% percent of the AIDS patients had a virus sensitive to inhibition by the $\beta$-chemokines. Statistical analyses indicated that the prevalence of $\beta$-chemokinesensitive virus in the AIDS group was significantly less than that seen in the asymptomatic group $(P=0.05)$. The finding of NSI viruses in AIDS patients, however, indicates that chemokine sensitivity is not consistently associated with an asymptomatic state, nor is progression linked to virus insensitivity to the $\beta$-chemokines. Thus, the $\beta$-chemokines do not appear to prevent development of disease.

Finally, in answer to the fourth question regarding the anti-

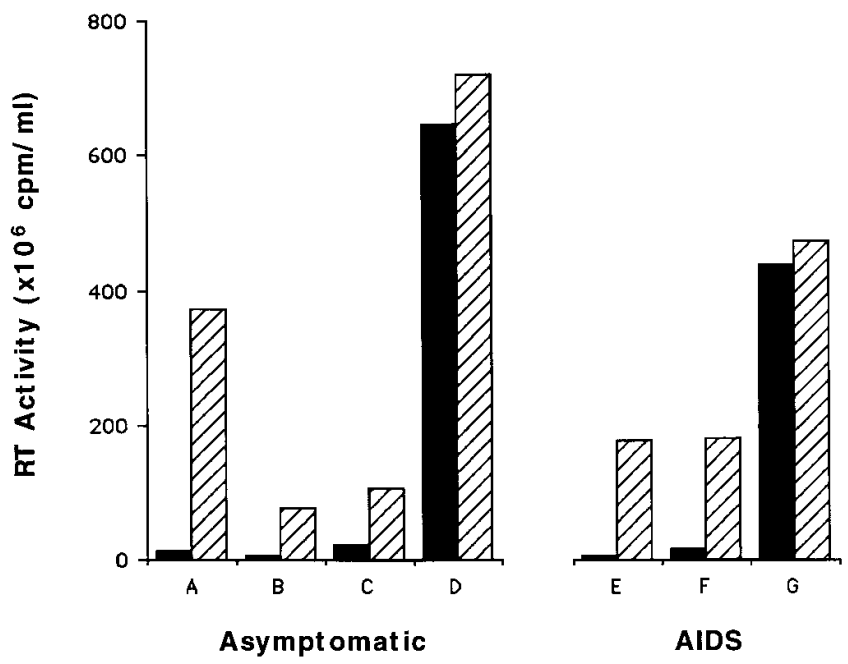

Figure 6. The effect of anti- $\beta$-chemokine neutralizing antibodies on HIV replication in naturally infected CD4+ T cells. CD4+ T cells isolated from HIV-infected asymptomatic subjects or AIDS patients were cultured in the continued presence of either a nonspecific control antibody $(250 \mu \mathrm{g} / \mathrm{ml})$ (solid bar) or a mixture of neutralizing antibodies specific to RANTES $(100 \mu \mathrm{g} / \mathrm{ml})$, MIP- $1 \alpha(50 \mu \mathrm{g} / \mathrm{ml})$ and MIP-1 $(100 \mu \mathrm{g} / \mathrm{ml})$ (striped bar). Subjects D and G harbored SI viruses; the other subjects harbored NSI viruses. The amount of HIV replication (indicated by RT activity) in the control antibody-treated culture fluid from the first passage with detectable RT activity (usually day 9-12) is shown. As measured by ELISA, culture fluids containing the mixture of antichemokine antibodies showed a complete neutralization of all three $\beta$-chemokines (data not shown).

viral activity of endogenously produced $\beta$-chemokines, replication of NSI, but not SI, HIV isolates was enhanced in the presence of neutralizing antibodies to the $\beta$-chemokines (Figs. 5 and 6$)$. The results indicate that the low levels of endogenously produced RANTES, MIP- $1 \alpha$ and MIP-1 $(<10 \mathrm{ng} / \mathrm{ml}$, each) can autoregulate NSI HIV production in naturally infected CD4+ T cells, as has been suggested by others (49). The naturally produced level of these cytokines, however, appears to delay, but not prevent, virus production and spread in CD4+ T cells (Fig. 5). The findings also support the above evidence that sensitivity to the $\beta$-chemokines is strictly dependent on the virus phenotype, and not necessarily the clinical state (Table I).

In summary, this study has provided further evidence that the $\beta$-chemokines, RANTES, MIP- $1 \alpha$, and MIP- $1 \beta$, can control virus replication of primary NSI, but not SI, HIV isolates in culture. The results do not, however, provide evidence of a substantial protective role of these $\beta$-chemokines in vivo. Nevertheless, the question remains whether these ligands for the HIV coreceptor CCR5 can select against NSI variants of HIV and affect the rate of NSI to SI switch seen in many HIVinfected individuals who progress to disease.

\section{Acknowledgments}

We would like to thank Drs. Michael Luther and Fred Kull (GlaxoWellcome Corporation, Research Triangle Park, NC) for providing the recombinant chemokines, neutralizing antibodies, and ELISA kits used in this study. Roland Orque, Sandra Lee, and Katharine Bossart 
are thanked for their technical assistance. We thank Ann Murai for help in preparation of the manuscript.

The research was supported by a grant from the National Institutes of Health (RO1AI30350). Giampaolo Greco was supported by an AIDS fellowship from the Instituto Superiore di Sanita, Rome, Italy; G. Reyes-Teran was a fellow under a Fogarty International AIDS Training Program (5 D43 TW00003-07).

\section{References}

1. Oppenheim, J.J., C.O.C. Zachariae, N. Mukaida, and K. Matsushima. 1991. Properties of the novel proinflammatory supergene intercrine cytokine family. Ann. Rev. Immunol. 9:617-648.

2. Ransohoff, R.M., A. Glabinski, and M. Tani. 1996. Chemokines in immune-mediated inflammation of the central nervous system. Cytokine Growth Factor Rev. 7:35-46.

3. Kunkel, S.L., N. Lukacs, T. Kasama, and R.M. Strieter. 1996. The role of chemokines in inflammatory joint disease. J. Leukocyte Biol. 59:6-12.

4. Lukacs, N.W., R.M. Strieter, S.W. Chensue, and S.L. Kunkel. 1996. Activation and regulation of chemokines in allergic airway inflammation. J. Leukocyte Biol. 59:13-17.

5. Brown, Z., R.L. Robson, and J. Westwick. 1996. Regulation and expression of chemokines: potential role in glomerulonephritis. J. Leukocyte Biol. 59: $75-80$.

6. Strieter, R.M., T.J. Standiford, G.B. Huffnagle, L.M. Colletti, N.W. Lukacs, and S.L. Kunkel. 1996. The good, the bad, and the ugly. The role of chemokines in models of human disease. J. Immunol. 157:3583-3586.

7. Cook, D.N., M.A. Beck, T.M. Coffman, S.L. Kirby, J.F. Sheridan, I.B. Prganell, and O. Smithies. 1995. Requirement of MIP-1 $\alpha$ for an inflammatory response to viral infection. Science (Wash. DC). 269:1583-1585.

8. Standiford, T.J., S.L. Kunkel, M.J. Greenberger, L.L. Laichalk, and R.M. Strieter. 1996. Expression and regulation of chemokines in bacterial pneumonia. J. Leukocyte Biol. 59:24-28.

9. Cocchi, F., A.L. DeVico, A. Garzino-Demo, S.K. Arya, R.C. Gallo, and P. Lusso. 1995. Identification of RANTES, MIP-1alpha, and MIP-1beta as the major HIV-suppressive factors produced by CD8+ T cells. Science (Wash. DC). 270:1811-1815.

10. Mackewicz, C.E., E. Barker, and J.A. Levy. 1996. Role of $\beta$-chemokines in suppressing HIV replication. Science (Wash. DC). 274:1393-1395.

11. Jansson, M., M. Popovic, A. Karlsson, F. Cocchi, P. Rossi, J. Albert, and H. Wigzell. 1996. Sensitivity to inhibition by $\beta$-chemokines correlates with biological phenotypes of primary HIV-1 isolates. Proc. Natl. Acad. Sci. USA. 93: $15382-15387$.

12. Alkhatib, G., C. Combadiere, C.C. Broder, Y. Feng, P.E. Kennedy, P.M. Murphy, and E.A. Berger. 1996. CC-CKR-5: a RANTES, MIP-1 $\alpha$, MIP-1 $\beta$ receptor as a fusion cofactor for macrophage-tropic HIV-1. Science (Wash. DC). 272:1955-1958

13. Dragic, T., V. Litwin, G.P. Allaway, S.R. Martin, Y. Huang, K.A. Nagashima, C. Cayanan, P.J. Maddon, R.A. Koup, J.P. Moore, and W.A. Paxton. 1996. HIV-1 entry into CD4+ cells is mediated by the chemokine receptor CCCKR-5. Nature (Lond.). 381:667-673.

14. Deng, H.K., R. Liu, W. Ellmeier, S. Choe, D. Unutmaz, M. Burkhart, P. Di Marzio, S. Marmon, R.E. Sutton, C.M. Hill, et al. 1996. Identification of a major co-receptor for primary isolates of HIV-1. Nature (Lond.). 381:661-666.

15. Choe, H., M. Farzan, Y. Sun, N. Sullivan, B. Rollins, P.D. Ponath, L. Wu, C.R. Mackay, G. LaRosa, W. Newman, et al. 1996. The $\beta$-chemokine receptors CCR3 and CCR5 facilitate infection by primary HIV-1 isolates. Cell. 85:1135-1148.

16. Feng, Y., C.C. Broder, P.E. Kennedy, and E.A. Berger. 1996. HIV-1 entry cofactor: functional cDNA cloning of a seven-transmembrane, $\mathrm{G}$ proteincoupled receptor. Science (Wash. DC). 272:872-877.

17. Berson, J.F., D. Long, B.J. Doranz, J. Rucker, F.R. Kirik, and R.W. Doms. 1996. A seven-transmembrane domain receptor involved in fusion and entry of T-cell-tropic human immunodeficiency virus type 1 strains. J. Virol. 70: 6288-6295.

18. Wu, L., N.P. Gerard, R. Wyatt, H. Choe, C. Parolin, N. Ruffing, A. Borsetti, A.A. Cardoso, E. Desjardin, W. Newman, et al. 1996. CD4-induced interaction of primary HIV-1 gp120 glycoproteins with the chemokine receptor CCR-5. Nature (Lond.). 384:179-183.

19. Oravecz, T., M. Pall, and M.A. Norcross. 1996. $\beta$-chemokine inhibition of monocytotropic HIV-1 infection. Interference with a postbinding fusion step. J. Immunol. 157:1329-1332.

20. Cocchi, F., A.L. DeVico, A. Garzino-Demo, A. Cara, R.C. Gallo, and P. Lusso. 1996. The V3 domain of the HIV-1 gp120 envelope glycoprotein is critical for chemokine-mediated blockade of infection. Nat. Med. 2:1244-1247.

21. Atchison, R.E., J. Gosling, F.S. Monteclaro, C. Franci, L. Digliio, I.F. Charo, and M.A. Goldsmith. 1996. Multiple extracellular elements of CCR5 and HIV-1 entry: dissociation from response to chemokines. Science (Wash. DC). 274:1924-1926.
22. Liu, R., W.A. Paxton, S. Choe, D. Ceradini, S.R. Martin, R. Horuk, M.E. MacDonald, H. Stuhlmann, R.A. Koup, and N.R. Landau. 1996. Homozygous defect in HIV-1 coreceptor accounts for resistance for some multiplyexposed individuals to HIV-1 infection. Cell. 86:367-377.

23. Samson, M., F. Libert, B.J. Doranz, J. Rucker, C. Liesnard, C.M. Farber, S. Saragosti, C. Lapoumeroulie, J. Cognaux, C. Forceille, et al. 1996. Resistance to HIV-1 infection in caucausian individuals bearing mutant alleles of the CCR-5 chemokine receptor gene. Nature (Lond.). 382:722-725.

24. Dean, M., M. Carrington, C. Winkler, G.A. Huttley, M.W. Smith, R. Allikmets, J.J. Goedert, S.P. Buchbinder, E. Vittinghoff, E. Gomperts, et al. 1996. Genetic restriction of HIV-1 infection and progression to AIDS by a deletion allele of the CKR5 structural gene. Science (Wash. DC). 273:1856-1861.

25. Castro, K.G., J.W. Ward, L. Slutsker, J.W. Buehler, H.W. Jaffe, R.L. Berkelman, and J.W. Curran. 1992. 1993 revised classification system for HIV infection and expanded surveillance case definition for AIDS among adolescents and adults. Morb. Mortal. Wkly. Rep. 41:1-19.

26. Hoffman, A.D., B. Banapour, and J.A. Levy. 1985. Characterization of the AIDS-associated retrovirus reverse transcriptase and optimal conditions for its detection in virions. Virology. 147:326-335.

27. Mackewicz, C.E., H. Ortega, and J.A. Levy. 1994. Effect of cytokines on HIV replication in CD4+ lymphocytes: lack of identity with the CD8+ cell antiviral factor. Cell. Immunol. 153:329-343.

28. McDougal, J.S., S.P. Cort, M.S. Kennedy, C.D. Cabridilla, P.M. Feorino, D.P. Francis, D. Hicks, V.S. Kalyanaraman, and L. S. Martin. 1985. Immunoassay for the detection and quantitation of infectious human retrovirus, lymphadenopathy-associated virus (LAV). J. Immunol. Meth. 76:171-183.

29. Koot, M., A.H.V. Vos, R.P.M. Keet, R.E.Y. de Goede, M.W. Dercksen, F.G. Terpstra, R.A. Coutinho, F. Miedema, and M. Tersmette. 1992. HIV-1 biological phenotype in long-term infected individuals evaluated with an MT-2 cocultivation assay. AIDS(Lond.). 6:49-54.

30. Mackewicz, C.E., H.W. Ortega, and J.A. Levy. 1991. CD8+ cell antiHIV activity correlates with the clinical state of the infected individual. J. Clin. Invest. 87:1462-1466.

31. Levy, J.A., L.H. Tobler, T.M. McHugh, C.H. Casavant, and D.P. Stites 1985. Long-term cultivation of T cell subsets from patients with acquired immune deficiency syndrome. Clin. Immunol. Immunopathol. 35:328-336.

32. Levy, J.A., C. Cheng-Mayer, D. Dina, and P.A. Luciw. 1986. AIDS retrovirus (ARV-2) clone replicates in transfected human and animal fibroblasts. Science (Wash. DC). 232:998-1001.

33. Evans, L.A., T.M. McHugh, D.P. Stites, and J.A. Levy. 1987. Differential ability of human immunodeficiency virus isolates to productively infect human cells. J. Immunol. 138:3415-3418.

34. Bluman, E.M., K.J. Bartynski, B.R. Avalos, and M.A. Caligiuri. 1996. Human natural killer cells produce abundant macrophage inflammatory protein-1 $\alpha$ in response to monocyte-derived cytokines. J. Clin. Invest. 97:27222727.

35. Zipfel, P.F., J. Balke, S.G. Irving, K. Kelly, and U. Siebenlist. 1989. Mitogenic activation of human $\mathrm{T}$ cells induces two closely related genes which share structural similarities with a new family of secreted factors. J. Immunol. 142:1582-1590.

36. Conlon, K., A. Lloyd, U. Chattopadhyay, N. Lukacs, S. Kunkel, T. Schall, D. Taub, C. Morimoto, J. Osborne, J. Oppenheim, et al. 1995. CD8+ and CD45RA+ human peripheral blood lymphocytes are potent sources of macrophage inflammatory protein $1 \alpha$, interleukin-8 and RANTES. Eur. J. Immunol. 25:751-756.

37. Schmidtmayerova, H., H.S.L. Nottet, G. Nuovo, T. Raabe, C.R. Flanagan, L. Dubrovsky, H.E. Gendelman, A. Cerami, M. Bukrinsky, and B. Sherry. 1996. Human immunodeficiency virus type 1 infection alters chemokine beta peptide expression in human monocytes: implications for recruitment of leukocytes into brain and lymph nodes. Proc. Natl. Acad. Sci. USA. 93:700-704.

38. Levy, J.A. 1994. HIV and the Pathogenesis of AIDS. ASM Press, Washington, D.C.

39. Sander, B., J. Andersson, and U. Andersson. 1991. Assessment of cytokines by immunofluorescence and the paraformaldehyde-saponin procedure. Immunol. Rev. 119:65-93.

40. Ridley, D.J., R.W. Houk, M.J. Reid, and R.N. Boswell. 1989. Early lymphocyte transformation abnormalities in human immunodeficiency virus infection. J. Clin. Immunol. 9:119-124.

41. Keet, I.P.M., A. Krol, M.R. Klein, P. Veugelers, J. de Wit, M. Roos, M. Koot, J. Goudsmit, F. Miedema, and R. A. Coutinho. 1994. Characteristics of long-term asymptomatic infection with human immunodeficiency virus type 1 in men with normal and low CD4+ cell counts. J. Infect. Dis. 169:1236-1243.

42. Gruters, R.A., F.G. Terpstra, R. De Jong, C.J.M. Van Noesel, R.A.W. Van Lier, and F. Miedema. 1990. Selective loss of T cell function in different stages of HIV infection. Early loss of anti-CD3-induced T cell proliferation followed by decreased anti-CD3-induced cytotoxic T lymphocyte generation in AIDS-related complex and AIDS. Eur. J. Immunol. 20:1039-1044.

43. Hofmann, B., R. Jakobsen, N. Odum, E. Dickmeiss, P. Platz, L.P. Ryder, C. Pedersen, L. Mathiesen, I. Bygbjerg, V. Faber, and A. Svejgaard. 1989 Relatively preserved phytohemagglutinin as opposed to decreased pokeweed mitogen responses may be due to possibly preserved responses via CD2/phytohemagglutinin pathway. J. Immunol. 142:1874-1880. 
44. Rubbert, A., D. Weissman, C. Combadiere, K.A. Pettrone, J.A. Daucher, P.M. Murphy, and A.S. Fauci. 1997. Multifactorial nature of noncytolytic CD8 + T cell-mediated suppression of HIV replication: $\beta$-chemokinedependent and -independent effects. AIDS Res. Hum. Retroviruses. 13:63-69.

45. Landay, A., B. Ohlsson-Wilhelm, and J.V. Giorgi. 1990. Application of flow cytometry to the study of HIV infection. AIDS. 4:479-497.

46. Blazevic, V., M. Heino, A. Ranki, T. Jussila, and K.J.E. Krohn. 1996. RANTES, MIP and interleukin-16 in HIV infection. AIDS. 10:1435-1436.

47. Clerici, M., C. Balotta, D. Trabattoni, L. Papagno, S. Ruzante, S. Rusconi, M.L. Fusi, M.C. Colombo, and M. Galli. 1996. Chemokine production in
HIV-seropositive long-term asymptomatic individuals. AIDS. 10:1432-1433.

48. Goudsmit, J. 1995. The role of viral diversity in HIV pathogenesis. $J$. Acquir. Immune Defic. Syndr. Hum. Retrovirol. 10:S15-S19.

49. Kinter, A.L., M. Ostrowski, D. Goletti, A. Oliva, D. Weissman, K. Gantt, E. Hardy, R. Jackson, L. Ehler, and A.S. Fauci. 1996. HIV replication in CD4+ T cells of HIV-infected individuals is regulated by a balance between the viral suppressive effects of endogenous $\beta$-chemokines and the viral inductive effects of other endogenous cytokines. Proc. Natl. Acad. Sci. USA. 93:1407614081. 